\title{
Does leverage level matter for return anomaly during rights issue announcements? The case of Islamic countries
}

\author{
Murat Isiker and Oktay Tas \\ Faculty of Management, Istanbul Technical University, Istanbul, Turkey
}

\begin{abstract}
Purpose - This paper aims to measure investors' perception of the rights issue announcement of publicly listed companies in five stock markets of Islamic countries. Then, these firms are grouped according to their debt level to examine whether abnormal returns are different from those that are highly leveraged. Moreover, Sharíah compatibility of firms is checked to understand if return anomaly shows different behaviour around rights issue announcement days.

Design/methodology/approach - The analysis period includes the years 2010-2019, which includes 362 rights issue announcements. The event study methodology is applied to measure the level of impact that is triggered by the rights issue announcements. Hereafter, one-way ANOVA test is performed to identify whether there exists a difference among the sample groups according to their debt level.

Findings - Findings suggest that rights issue announcements cause $-3.90 \%$ fall in share prices on average for the whole sample. However, negative abnormal return is found significant only in Egypt and Turkey. Individual regression analysis results suggest that an increase in debt level worsens the return anomaly only in Egypt. This refers that the rights issue announcement is perceived as less favourable for highly leveraged companies compared to others in this country. Finally, Sharic ah-compliant companies show better performance compared to non-compliant counterparts around the event dates.

Originality/value - This paper is novel in evaluating market reaction during rights issue announcements in multiple Islamic countries. Also, to the best of the authors' knowledge, this study is the first attempt to compare return behaviour of Sharíah-compliant and non-compliant firms around the rights issue announcements.
\end{abstract}

Keywords Rights issue, Return anomaly, Announcement effect, Sharíah compliance, Leverage level,

Event study methodology

Paper type Research paper

\section{Introduction and literature review}

The rights issue is a method of raising capital for companies by addressing their existing shareholders. Investors, who do not want to face dilution, must participate in the offering and inject new capital on a rate that is announced by the company board. On the other hand, those who reject to participate in this offering may sell their pre-emptive rights on the market, which will result in a decrease in their existing ownership proportion. Perception of investors to the rights issue news differs according to companies' profile. If investors believe that the company will use the new capital for profitability or long-term growth concerns, then they may react positively to the announcement. However, if they evaluate this news as a bad signal, which means that the company is not performing well operationally or financially, then the reaction can be negative.

\section{JEL Classification — G4, G14, G15, G32. KAUJIE Classification - I72, I76}

(C) Murat Isiker and Oktay Tas. Published in Islamic Economic Studies. Published by Emerald Publishing Limited. This article is published under the Creative Commons Attribution (CC BY 4.0) licence. Anyone may reproduce, distribute, translate and create derivative works of this article (for both commercial and non-commercial purposes), subject to full attribution to the original publication and authors. The full terms of this licence may be seen at http://creativecommons.org/licences/by/4.0/legalcode

This paper is based on the $\mathrm{PhD}$ thesis of Murat Isiker.

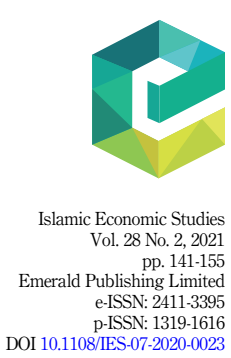


IES

28,2

The rights issue is not popular in developed markets as it is in emerging ones. Tan et al. (2002) claim that the rights issue does not attract companies in countries where developed bond markets and tax advantages of issuing bonds exist. Despite non-popularity in developed markets, a group of studies aims to understand market reaction around the rights issue announcements. Common findings of the US-based studies report negative market reaction occurring after the rights issue announcements (Hansen, 1988; Eckbo and Masulis, 1992; Heron and Lie, 2004). Apart from studies in the USA, Slovin et al. (2000) report -3.09\% cumulative average abnormal return (CAAR) for $(-1,0)$ event window (specific period of time to measure event's impact) in the UK; Kabir and Roosenboom (2003) indicate $-2.79 \%$ CAAR for $(0,1)$ in the Netherlands; Adaoglu (2006) finds $-7.06 \%$ fall in share prices on average in Turkey for (0, 5); Balachandran et al. (2012) show -1.99\% CAAR for $(-1,1)$ in Australia; and Kim and Song (2020) report - 10.5\% CAAR for $(0,5)$ in South Korea. Holderness and Pontiff (2016) suggest that one reason behind negative reaction is the lack of enthusiasm to participate in the offerings. For example, the average participation rate by investors in rights issues is $64 \%$ in the USA. On the other hand, a positive excess return is reported in Japan by Kang and Stulz (1996), which is around $2.20 \%$ for $(-1,1)$ event window; in Greece by Tsangarakis (1996), which is about $3.90 \%$ for $(-1,0)$; in Singapore by Tan et al. (2002), which is approximately $2 \%$ within 3-day event window; and in Kuwait by Alhashel and Alojayan (2015), which is around $\% 5$ for $(-2,2)$. Ariff et al. (2007) assert that rights issue announcements can be perceived as favourable if the appetite for high growth exists in a country. Also, Mateus et al. (2017) suggest that if there are firm-specific future growth opportunities, a positive market reaction is obtained.

Leverage level of companies that apply rights issues is affected in two ways. One is a direct effect, since the debt-to-equity ratio becomes lesser as a result of raised capital. The second reason is that the company may prefer to decrease the debt level by paying the loans back to the creditors. For example, Kim et al. (2019) suggest that one-third of raised capital after rights issuance is used in debt restructuring in South Korea. Thus, we aim to analyze whether the market reaction is affected according to different debt levels. Lee et al. (2014) show that abnormal returns for non-financial firms are higher for highly leveraged companies. Sartika et al. (2016) claim that in Indonesia, the debt level has a positive association with abnormal returns. Authors conclude that highly leveraged companies, which announce rights issues, provide favourable signals for future growth. However, Tan et al. (2002) and Alhashel and Alojayan (2015) assert that change in debt level does not affect the market reaction in Singapore and Kuwait. Iqbal (2008) reports that market reaction to the rights issues is more negative for those firms that announce to use the new capital for the debt reduction purpose rather than new investment projects.

Leverage level is also crucial in Sharíah-compliant investment. Financial screening limits the Shariah-compliant companies to have no more than one-third of a debt level over their total assets or market capitalization. (Some institutions such as Meezan Islamic Fund in Pakistan and Participation Index in Turkey apply different benchmark levels for this criterion.) Since Shariah-compliant companies are assumed to be less-leveraged than noncompliant peers, they are expected to be more resistant against market downturns (Bhatt and Sultan, 2012; Saiti et al., 2014; Farooq and AbdelBari, 2015; Ismail, 2015; Ashraf et al., 2017). Since the majority of the studies in the literature suggest that rights issue announcements result in a fall on average in share prices, it is worth to analyze and compare the return performance of the Shariah-compliant and non-compliant companies during this corporate event. Comparison of return performance for compliant and non-compliant financial instruments is documented in many studies (Al-Khazali et al., 2014; Jawadi et al., 2014; Tas et al., 2016; Rejeb and Arfaoui, 2019). However, this paper aims to concentrate more on the return anomaly that is triggered by a specific corporate event and how this anomaly occurs for compliant and non-compliant firms in the sample countries. 
This paper is novel in evaluating market reaction during rights issue announcements in multiple Islamic countries. Also, to the best of our knowledge, this study is the first attempt to compare return behaviour of Shari ${ }^{-1}$ h-compliant and non-compliant firms around the rights issue announcement days. The rest of the paper is organized as follows. The next section describes the data and research design, the third section evaluates the paper's findings and the last section is reserved for the conclusion.

\section{Data and methodology}

Rights issue announcement data were extracted from Thomson Reuters Eikon database for the countries of Egypt, Malaysia, Pakistan, Saudi Arabia and Turkey. Since the concern of the paper is dealing with the impact of rights issue announcements in Islamic countries, data for other countries such as Bahrain, Indonesia, Kuwait, Morocco, Oman, Qatar and UAE are also checked. Due to an insufficient number of announcements or missing price data for stocks, these countries are excluded from the analysis. Table 1 shows the number of announcements for each year and each country with their corresponding indices.

Daily price data are used in the analysis to find abnormal returns. Also, the ratio of totaldebt-to-total-assets, which is used by Lee et al. (2014), is preferred to measure the debt level of the companies. Data for both variables are extracted by using the Datastream database.

To measure abnormal return after the rights issue announcement, event study methodology is performed for each country, and then for the pooled sample. There are certain steps to perform this technique. These are described and defined as follows:

\subsection{Definition of the event}

First of all, the event must be identified. In this study, the rights issue announcement is stated as the event. Also, the announcement day is set as $t=0$.

\subsection{Estimation period}

As a second step, the estimation period and estimation windows must be determined. To find the expected return of a security, estimation period is set as a specific period before the event. Since daily expected return calculation is considered for this study, the estimation period will be 240 days, which is approximately the number of trading days in a year, which is suggested

\begin{tabular}{|c|c|c|c|c|c|}
\hline $\begin{array}{l}\text { Countries } \\
\text { Reuters instrument } \\
\text { codes (RICs) }\end{array}$ & $\begin{array}{l}\text { Egypt } \\
\text { EGX100 } \\
\text { EGX 100 } \\
\text { index }\end{array}$ & $\begin{array}{c}\text { KLFT100 } \\
\text { FTSE Bursa } \\
100 \text { index }\end{array}$ & $\begin{array}{l}\text { Pakistan } \\
\text { KSE } \\
\text { KSE } 100 \\
\text { index }\end{array}$ & $\begin{array}{c}\text { Saudi Arabia } \\
\text { TASI } \\
\text { TADAWUL FF } \\
\text { index }\end{array}$ & $\begin{array}{c}\text { Turkey } \\
\text { XUTUM } \\
\text { BIST all shares } \\
\text { index }\end{array}$ \\
\hline 2019 & 4 & 0 & 3 & 10 & 25 \\
\hline 2018 & 8 & 2 & 3 & 7 & 28 \\
\hline 2017 & 7 & 7 & 8 & 4 & 16 \\
\hline 2016 & 4 & 2 & 2 & 4 & 8 \\
\hline 2015 & 8 & 5 & 6 & 4 & 7 \\
\hline 2014 & 7 & 7 & 5 & 10 & 12 \\
\hline 2013 & 8 & 8 & 4 & 4 & 9 \\
\hline 2012 & 0 & 3 & 1 & 3 & 16 \\
\hline 2011 & 5 & 7 & 6 & 2 & 18 \\
\hline 2010 & 7 & 2 & 5 & 5 & 26 \\
\hline Total & 58 & 43 & 43 & 53 & 165 \\
\hline
\end{tabular}

Source(s): Thomson Reuters Eikon; author's calculation

\section{Does leverage} level matter?

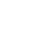

(


by Armitage (1995). Thus, the estimation window is determined as $(-250,-11)$. On the other hand, event windows are the number of days that the impact is averaged and cumulated to understand the anomaly that is caused by the event. In this study, we use six different event windows. Kothari and Warner (2007) assert that expanding event windows may cause to lose the ability to detect the true effect of the event. Thus, short event windows are preferred in this study. To see the entire effect of the announcement, two different event windows, $(-10$, $10)$ and $(-5,5)$, are used. For the pure announcement effect, five and ten days after the eventday periods are assigned (i.e. $(0,5)$ and $(0,10))$. Lastly, to check whether there is an insider trading activity, $(-10,-1)$ and $(-5,-1)$ windows are preferred.

\subsection{Expected return calculation}

To find the impact of the defined event, we need to calculate the abnormal (actual) return, which is simply the difference between expected and realized returns of a security. Constant mean return (CMR) model is used to find expected returns. In this model, the expected return of a security is calculated by aggregating returns that are realized within the estimation period and divided by 240 days. In other words, the expected return is the average of returns of the trading days approximately one year prior to the event.

Thus, $\mu_{i}$ is the average return of security $i$ during the estimation period, where $R_{i, t}$ is the realized return of security $i$ at time $t$, and $\varepsilon_{i, t}$ represents the deviation from the average in the event date for security $i$. CMR can be formulated as follows:

$$
R_{i, t}=\mu_{i}+\varepsilon_{i, t}
$$

When we subtract the actual with the expected return for security $i$, we obtain the abnormal return for a specified event window. Thus, we can rewrite the equation as follows:

$$
\varepsilon_{i, t}=R_{i, t}-\mu_{i}
$$

\subsection{Statistical tests}

Abnormal returns need to be tested statistically to understand whether they are significantly different from zero or not. CAAR is hypothesized as follows:

$$
H_{0}: \operatorname{CAAR}_{\left(t_{x}, t_{y}\right)}=0, H_{1}: \operatorname{CAAR}_{\left(t_{x}, t_{y}\right)} \neq 0
$$

where $\left(t_{x}, t_{y}\right)$ is the related event window in the analysis. Also, CAAR is formulated in equation (3) and (4) as follows:

$$
\mathrm{CAR}_{i,\left(t_{x}, t_{y}\right)}=\sum_{t_{x}}^{t_{y}} \mathrm{AR}_{i, t}
$$

$\mathrm{AR}_{i, t}$ is the abnormal return of each security on a single day within the event window, and $\mathrm{CAR}_{i,\left(t_{x}, t_{y}\right)}$ is the aggregation of abnormal returns.

$$
\operatorname{CAAR}_{\left(t_{x}, t_{y}\right)}=\frac{1}{N} \sum_{i=1}^{N} \operatorname{CAR}_{i,\left(t_{x}, t_{y}\right)}
$$

Cross-sectional $t$-test and generalized sign test that is formulated in Cowan (1992) are used to test the null hypothesis that is stated above. We prefer to use both methods to obtain more profound results.

Moreover, one-way ANOVA is performed to investigate whether abnormal returns differ according to different debt-level groups. Debt levels are grouped into four by using quartile 
ranges. Table 2 shows debt-level groups according to the variable of total-debt-to-total assets (TDTAs) ratio. Group 1 represents companies with low leverage level, while Group 4 consists of highly leveraged companies.

Thus, one-way ANOVA test is hypothesized as follows:

$$
H_{0}: \mu_{1}=\mu_{2}=\mu_{3}=\mu_{4}
$$

$H_{1}$ : At least one group is different than others

Apart from one-way ANOVA, we use the ordinary least square (OLS) method to see the explanatory power of debt level on abnormal returns for each country.

Hence, equation (5) shows the simple regression model as follows:

$$
\mathrm{CAR}_{i,\left(t_{x}, t_{y}\right)}=\beta_{0, i}+\beta_{1} \mathrm{TDTA}_{i}+\varepsilon_{i}
$$

Finally, $t$-test for two independent samples is applied to find whether there exists a difference in abnormal return means for Sharíah-compliant and non-compliant groups. We expect to obtain better performance from Shariah-compliant companies since rights issue announcements cause a fall in share prices in general, as documented in most of the papers in the literature. Thus, our hypothesis for this part is that CAR (cumulative abnormal returns) for Sharíah-compliant firms is not different from non-compliant firms. Sharíahcompliant firm lists are available for all countries except Egypt. Due to data unavailability, Egypt is not included for this part of the analysis. Shariah-compliant list of the Shariah Advisory Council of Securities Commission Malaysia is used for Malaysian companies. For Pakistani firms, the list of Al Meezan Investment Group is taken into consideration. Screening of three institutions, which are named as Al Rajhi Capital, Alinma Investment and Albilad Capital, is used for Saudi Arabian firms. A company is excluded from the sample of Shariahcompliant group if one of these three institutions does not confirm the compatibility of this company. Finally, for the Turkish case, two available sources announce Shariah-compliant companies' list every quarter. These are BMD Securities and Ziraat Participation Index. If a company is mentioned on the Shariah-compliant by both sources, then it is included in the sample. In total, a group of 98 Shariah-compliant and 207 non-compliant companies are included in the sample groups.

\section{Empirical findings}

\subsection{Event study results for return anomaly}

Rights issue announcements that occurred during the period 2010-2019 in five Islamic countries are analyzed under the event study methodology. First, abnormal returns for the pooled sample are calculated, and then the country-specific analysis is conducted. Table 3 shows the test results for CAAR under six different event windows. Findings suggest that significant return anomaly is detected for the pooled sample when the event window covers before and after announcement periods. Findings of this paper are in line with existing literature (Hansen, 1988; Eckbo and Masulis, 1992; Kabir and Roosenboom, 2003; Heron and Lie, 2004; Balachandran et al., 2012). Negative return anomaly seems concentrated more on

\begin{tabular}{lccccrrr}
\hline Debt level groups & Obs. & Mean & Std. dev. & Min & Max & & $\begin{array}{r}\text { Table 2. } \\
\text { Group 1 }\end{array}$ \\
Group 2 & 70 & 5.803 & 4.082 & 0.04 & 13.07 & $\begin{array}{r}\text { Debt-level quartiles } \\
\text { Group 3 }\end{array}$ \\
Group 4 & 69 & 23.134 & 5.249 & 13.28 & 30.77 & according to the total- \\
& 70 & 37.932 & 4.464 & 31 & 47.07 & debt-to-total- \\
assets ratio
\end{tabular}

Does leverage level matter?

\section{$+$}


IES
28,2

\begin{tabular}{|c|c|c|c|c|c|c|c|}
\hline & $\begin{array}{l}\text { Event } \\
\text { windows }\end{array}$ & $(-10,10)$ & $(-10,-1)$ & $(0,10)$ & $(-5,5)$ & $(-5,-1)$ & $(0,5)$ \\
\hline All & CAAR & $-4.00 \%$ & $0.57 \%$ & $-4.58 \%$ & $-3.80 \%$ & $0.11 \%$ & $-3.91 \%$ \\
\hline countries & Cross-sec & $-4.271 * * *$ & 0.902 & $-6.408^{* * *}$ & $-5.427 * * *$ & 0.272 & $-6.597^{* * *}$ \\
\hline \multirow[t]{3}{*}{$N=362$} & Prob. & 0.000 & 0.367 & 0.000 & 0.000 & 0.786 & 0.000 \\
\hline & Sign test & $-2.992 * * *$ & 1.123 & $-5.524 * * *$ & $-5.313 * * *$ & 0.806 & $-5.313^{* * * *}$ \\
\hline & Prob. & 0.003 & 0.261 & 0.000 & 0.000 & 0.420 & 0.000 \\
\hline Egypt & CAAR & $-5.63 \%$ & $-1.02 \%$ & $-4.61 \%$ & $-4.07 \%$ & $-0.41 \%$ & $-3.66 \%$ \\
\hline \multirow[t]{4}{*}{$N=58$} & Cross-sec & $-2.360 * *$ & -0.725 & $-2.341^{* *}$ & $-2.210 * *$ & -0.468 & $-2.327^{* *}$ \\
\hline & Prob. & 0.018 & 0.468 & 0.019 & 0.027 & 0.639 & 0.020 \\
\hline & Sign test & -1.341 & -0.552 & $-2.393^{* *}$ & -1.078 & -0.288 & $-2.131^{* *}$ \\
\hline & Prob. & 0.180 & 0.581 & 0.017 & 0.281 & 0.773 & 0.033 \\
\hline Malaysia & CAAR & $-0.94 \%$ & $0.56 \%$ & $-1.50 \%$ & $-1.33 \%$ & $0.31 \%$ & $-1.65 \%$ \\
\hline \multirow[t]{4}{*}{$N=43$} & Cross-sec & -0.638 & 0.533 & -1.369 & -1.173 & 0.502 & $-1.842^{*}$ \\
\hline & Prob. & 0.523 & 0.594 & 0.171 & 0.241 & 0.616 & 0.065 \\
\hline & Sign test & 0.775 & 0.4691 & -1.063 & $-1.676^{*}$ & 0.469 & -0.756 \\
\hline & Prob. & 0.438 & 0.639 & 0.288 & 0.094 & 0.639 & 0.449 \\
\hline Pakistan & CAAR & $-2.93 \%$ & $-0.73 \%$ & $-2.20 \%$ & $-3.50 \%$ & $-1.05 \%$ & $-2.45 \%$ \\
\hline \multirow[t]{4}{*}{$N=43$} & Cross-sec & -0.974 & -0.442 & -1.042 & $-1.696^{*}$ & -0.913 & -1.571 \\
\hline & Prob. & 0.330 & 0.659 & 0.297 & 0.090 & 0.361 & 0.116 \\
\hline & Sign test & $-2.072^{* *}$ & -0.542 & $-1.766^{*}$ & $-2.990 * * *$ & -0.542 & $-2.072^{* *}$ \\
\hline & Prob. & 0.038 & 0.588 & 0.077 & 0.003 & 0.588 & 0.038 \\
\hline Saudi & CAAR & $0.00 \%$ & $1.76 \%$ & $-1.76 \%$ & $-0.10 \%$ & $0.43 \%$ & $-0.53 \%$ \\
\hline Arabia & Cross-sec & -0.002 & 0.972 & -1.491 & -0.073 & 0.426 & -0.476 \\
\hline \multirow[t]{3}{*}{$N=53$} & Prob. & 0.998 & 0.331 & 0.136 & 0.942 & 0.670 & 0.634 \\
\hline & Sign test & -0.069 & 0.755 & -0.895 & -0.345 & 0.755 & -0.345 \\
\hline & Prob. & 0.945 & 0.450 & 0.371 & 0.730 & 0.450 & 0.730 \\
\hline Turkey & CAAR & $-5.81 \%$ & $1.10 \%$ & $-6.90 \%$ & $-5.63 \%$ & $0.44 \%$ & $-6.06 \%$ \\
\hline \multirow[t]{4}{*}{$N=165$} & Cross-sec & $-3.865 * * *$ & 1.040 & $-5.832^{* * * *}$ & $-4.880 * * *$ & 0.643 & $-6.084^{* * * *}$ \\
\hline & Prob. & 0.000 & 0.298 & 0.000 & 0.000 & 0.520 & 0.000 \\
\hline & Sign test & $-2.939 * * *$ & 1.602 & $-4.818^{* * * *}$ & $-4.661 * * *$ & 0.976 & $-4.974 * * *$ \\
\hline & Prob. & 0.003 & 0.109 & 0.000 & 0.000 & 0.329 & 0.000 \\
\hline
\end{tabular}

Table 3.

Cumulative average abnormal returns for the sampled countries
Note(s): CAAR refers to cumulative average abnormal return, which is the multi-day effect indicator. Event windows are shown in paranthesis. Cross-sec represents cross-sectional $t$-test statistics results. $*_{p}<0.1$, $* * p<0.05, * * * p<0.01$

post-announcement periods. After five days of the event occurrence, $-3.91 \%$ CAAR is detected. However, it deteriorates to $-4.58 \%$ until the 10 th day. Post-announcement period's abnormal returns for Egypt and Turkey are strong since both tests approve the presence of the anomaly. Sign test results fail to reject abnormal returns of Egypt for $(-5,5)$ and $(-10,10)$ event wdows. However, the results of the post-announcement periods for 5 and 10 days are significant at $5 \%$ level for this country. Investors in Turkey react to rights issue announcements as not favourable news, since the worst return performance, which is around $-6 \%$ for the $(0,5)$ event window, is recorded among the sample countries. This result is in line with Adaoglu (2006) who finds around $-7 \%$ return anomaly for the same event window in Turkey. Although return anomaly is detected in Pakistan, it is not strong since the anomaly case occurs only for $(-5,5)$ event window. Cross-sectional $t$-test statistics result is slightly above the $10 \%$ level, which is the failure of the robustness for $(0,5)$ event window. Nonetheless, $-2.45 \%$ CAAR is calculated in this country, which is the third-lowest after Turkey and Egypt. On the other hand, for Malaysia and Saudi Arabia, none of the cases is found significant, which means that there is no return anomaly during rights issue announcements in these countries. Finally, insider trading activity, which can be observed by obtaining abnormal return movements before the event occurrence, is not detected for all countries. 
A possible explanation for negative market reaction could be the profile of the stock market investors. Short-term investors who mostly trade just for speculation purpose may not welcome the rights offerings (Adaoglu, 2006). Since most of them try to increase their capital via daily price changes, they may not want to wait until the end of the rights issue process, which normally takes more than a month. Thus, after receiving this news, short-term investors more likely decide to sell their shares, which may cause a fall in the share price.

Figures 1 and 2 demonstrate how the total effect is formed around the event days in the sample countries. In Figure 1, multiple-day effects are presented by using CAAR data. However, to see the single-day abnormal return variations around the event day, average abnormal returns (AARs) are shown in Figure 2. To make a better comparison among countries, the vertical axis of each figure is determined as the same. In Egypt, Pakistan and Turkey, the impact of rights issue announcements on stocks' return is seen after the event takes place.

\subsection{The effect of leverage level on abnormal returns}

One-way ANOVA analysis is applied to investigate whether abnormal returns differ according to the companies' debt levels. Companies are divided into four groups according to the quartile ranges of debt levels. The first quartile represents companies with low leverage level, while the fourth quartile includes highly leveraged companies. Figure 3 demonstrates the box-plots of these quartiles according to abnormal return levels. Visually, it seems the medians of groups are not different from each other. However, all medians are calculated below zero. This refers that regardless of the debt level, rights issue announcements are received as bad news by the investors in sampled countries. One-way ANOVA provides statistical results to interpret the findings. Table 4 includes the CARs findings for $(0,5)$ and $(0$, 10) event windows. In both cases, models are found insignificant. Thus, the null hypothesis of one-way ANOVA, which refers that there is no difference in means across groups, cannot be rejected. This means that the CAR level for the pooled sample does not change according to the leverage level of companies. Findings of ANOVA analysis are in line with Tan et al. (2002) and Alhashel and Alojayan (2015).

To further analyze the debt level's impact on abnormal returns, OLS regression is performed for the pooled sample and each country separately. CAR for each country is regressed with the companies' debt-level variable, which is the total-debt-to-total-assets ratio, for the post-announcement periods. Findings suggest that debt-level coefficient is significant only in Egypt for both event windows. A negative sign represents that return anomaly is worse for the highly leveraged companies compared to less-leveraged ones. Results for Egypt are not consistent with Lee et al. (2014) and Sartika et al. (2016) who assert that abnormal return is positively associated with high debt level. The reason for this can be country-specific factors such as the availability of debt-financing opportunities. Although the remaining sample countries' results are not significant, the debt-level coefficient for the pooled sample is significant at the $10 \%$ level. To check the robustness of the results that are documented in Panels $A$ and $B$ of Table 5, we use a proxy variable for leverage level, which is the total-debtto-total-capital ratio. According to the findings in Panel C, the coefficient for the pooled sample becomes insignificant for both event windows. However, the negative and significant result is still valid in Egypt even though the explanatory power of variation is decreased slightly.

\subsection{The effect of Shariah compliance on return anomaly}

The last part of the analysis compares the means of CARs for Sharíah-compliant and noncompliant groups. Two sample independent $t$-test results in Panel A of Table 6 suggest that average of CAR for Shariah-compliant firms is statistically different from the CAR of noncompliant firms for $(0,10)$ event window. Both groups reacted negatively to the rights issue 
IES

28,2

148
All countries, CMR, CAAR $(-\mathbf{1 0}, 10)$

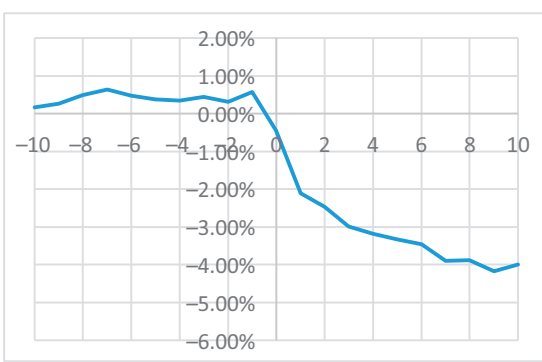

Malaysia, CMR, CAAR $(-10,10)$

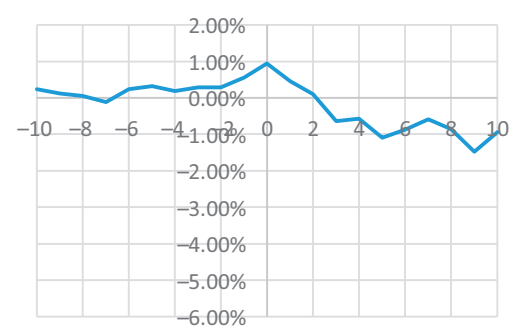

Saudi Arabia, CMR, CAAR $(-10,10)$

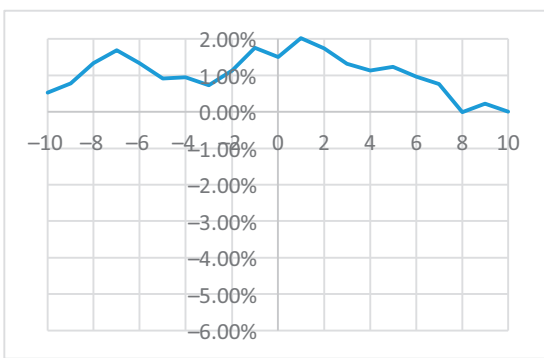

Egypt, CMR, CAAR $(-10,10)$

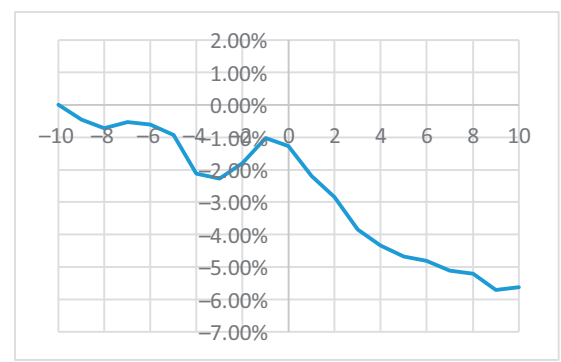

Pakistan, CMR, CAAR $(-\mathbf{1 0}, 10)$

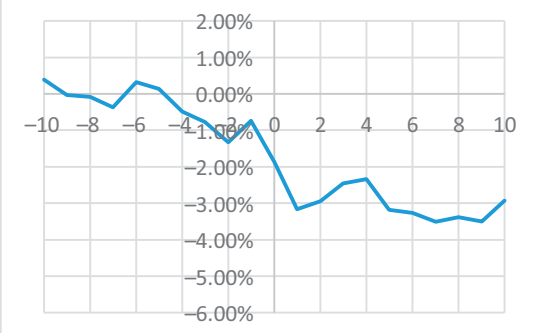

Turkey, CMR, CAAR (-10,10)

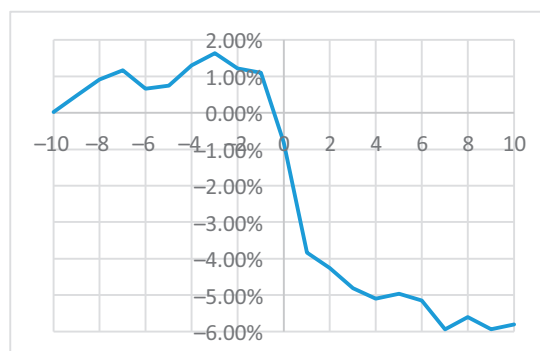

Figure 1.

Cumulative average abnormal return results in 21 days around the event according to the constant return model
Note(s): CAAR refers to cumulative average abnormal return, which is the multi-day effect indicator. $(-10,10)$ is the event window 21 days around the rights issue announcment and $t=0$ is the event day. CMR means constant mean return model

announcements. However, when two means are compared in magnitude, the mean of the noncompliant group is lesser by $3.80 \%$ than the compliant ones. Nonetheless, although abnormal returns for Shariah-compliant group is less negative than non-compliant group for $(0,5)$ event window, as it is described in Panel $\mathrm{B}$, we cannot conclude that average of CARs is statistically different. Thus, we conclude that results differ according to event window selection. However, in both cases, Shariah-compliant companies perform better. To further compare these two groups, we extend the event window as $(-10,20)$ to see 30 -day abnormal return behaviours. Here, the aim is to understand at which day CAAR for Sharíah-compliant portfolio reaches the break-even point. Figure 4 shows that abnormal returns for both groups act in the same direction and deteriorate until the 5th day for the post-announcement period. 
All Countries, CMR, AAR (-10,10)

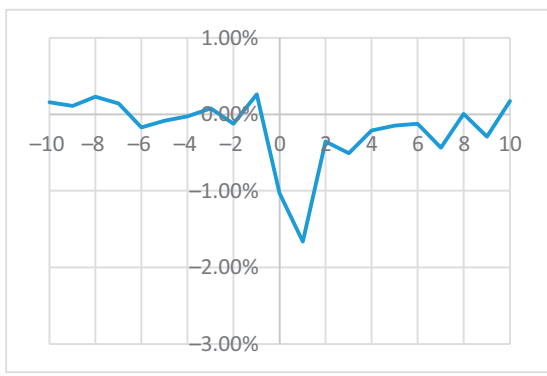

Malaysia, CMR, AAR $(-\mathbf{1 0 , 1 0})$

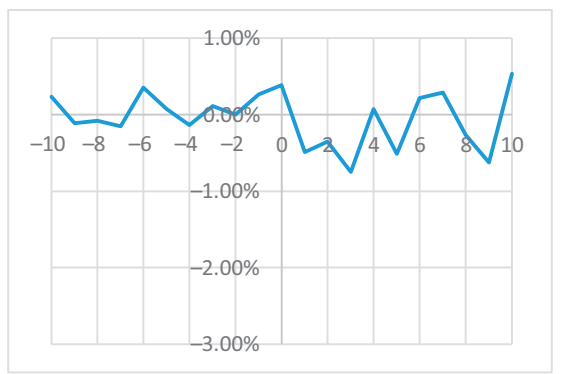

Saudi Arabia, CMR, AAR (-10,10)

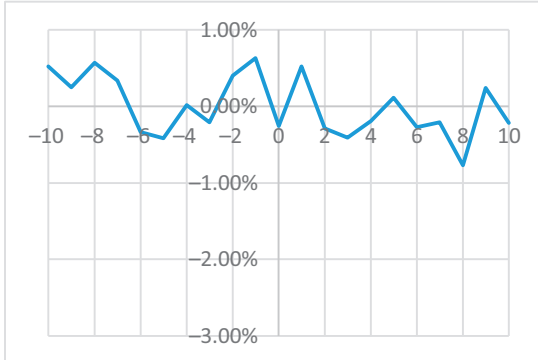

Egypt, CMR, AAR (-10,10)

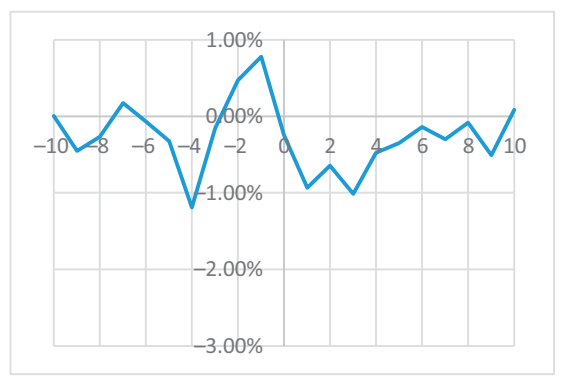

Pakistan, CMR, AAR (-10,10)

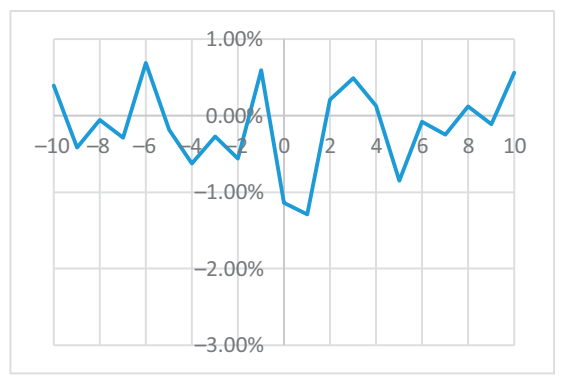

Turkey, CMR, AAR (-10,10)

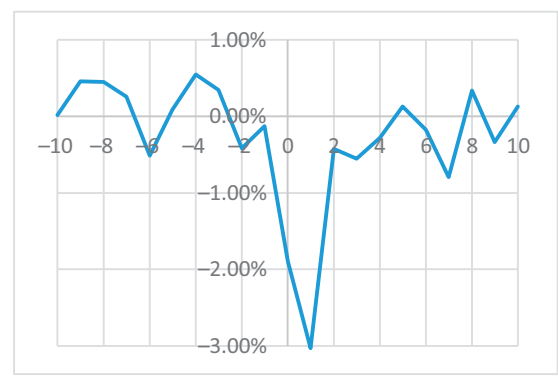

Note(s): AAR refers to average abnormal return, which is the single-day effect indicator. $(-10,10)$ is the event window 21 days around the rights issue announcment and $t=0$ is the event day. CMR means constant mean return model

Does leverage level matter?
Figure 2.

Average abnormal return results 21 days around the event according to the CMR

Then, Shariah-compliant firms start to recover the losses and reach the break-even abnormal return level at the end of the 18th day after the event. However, abnormal returns for noncompliant firms continue to decrease until the end of the analysis period. This refers that negative reaction is temporary for compliant firms.

There can be two reasons to explain this movement. First, Sharīah-compliant companies are more resistant to market downturns, thanks to the less risky nature as mentioned in Saiti et al. (2014), Alam and Rajjaque (2016) and Ashraf et al. (2017). This assertation is consistent with the findings of this paper. Second, the credibility of non-compliant firms could be lower than their compliant counterparts. Investors may conclude that the ability to increase 


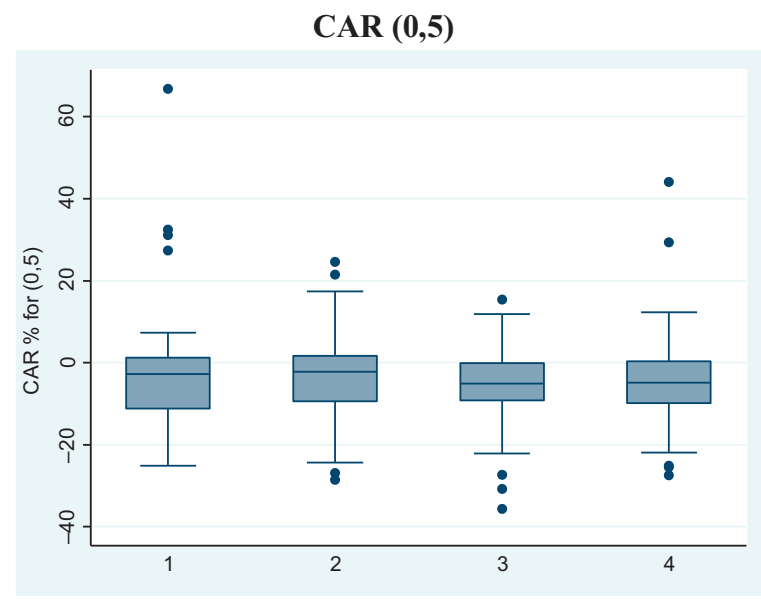

Figure 3.

Box-plots of cumulative abnormal returns for each debt level group under $(0,5)$ and $(0,10)$ event windows, respectively
CAR (0,10)

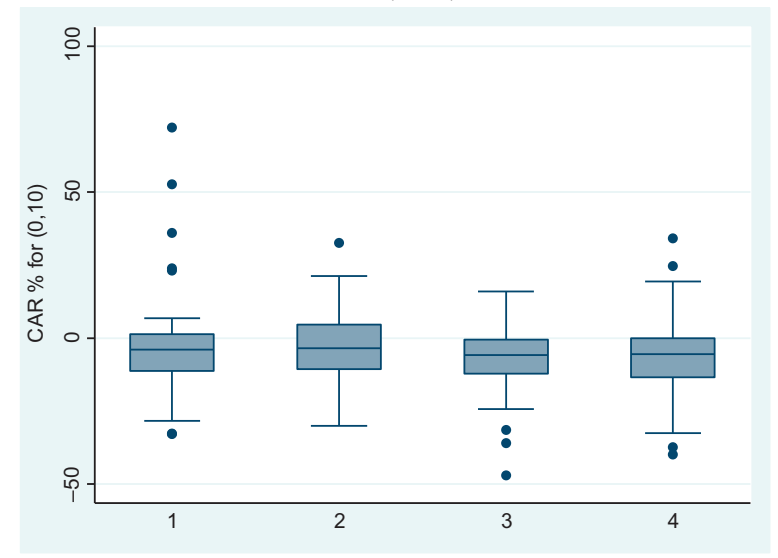

Panel A: CAR for $(0,5)$ event window

Number of obs $=280$

$\begin{array}{lll}\text { Root MSE } & =11.28\end{array}$

Source

TDTA_4

Residuals

Total

Partial SS 364.69

35125.15

35489.84

Panel B: CAR for $(0,10)$ event window

Number of obs $\quad=\quad 280$

Root MSE

13.63

Source

TDTA_4

Residuals

Table 4.

Total

405.70

51241.11

51646.81

$\begin{array}{rr}= & 0.0103 \\ = & -0.0005 \\ & \text { Prob }>F \\ & 0.4144\end{array}$

$\begin{array}{rr}= & 0.0103 \\ = & -0.0005 \\ & \text { Prob }>F \\ & 0.4144\end{array}$

$\begin{array}{rr}= & 0.0103 \\ = & -0.0005 \\ & \text { Prob }>F \\ & 0.4144\end{array}$

$\begin{array}{rr}= & 0.0103 \\ = & -0.0005 \\ & \text { Prob }>F \\ & 0.4144\end{array}$

$276 \quad 127.27$

$279 \quad 127.20$

Note(s): CAR refers to cumulative abnormal returns; TDTA_4 refers to four different groups according to the total-debt-to-total-assets ratio. $(0,10)$ and $(0,5)$ are event windows for after announcement periods 


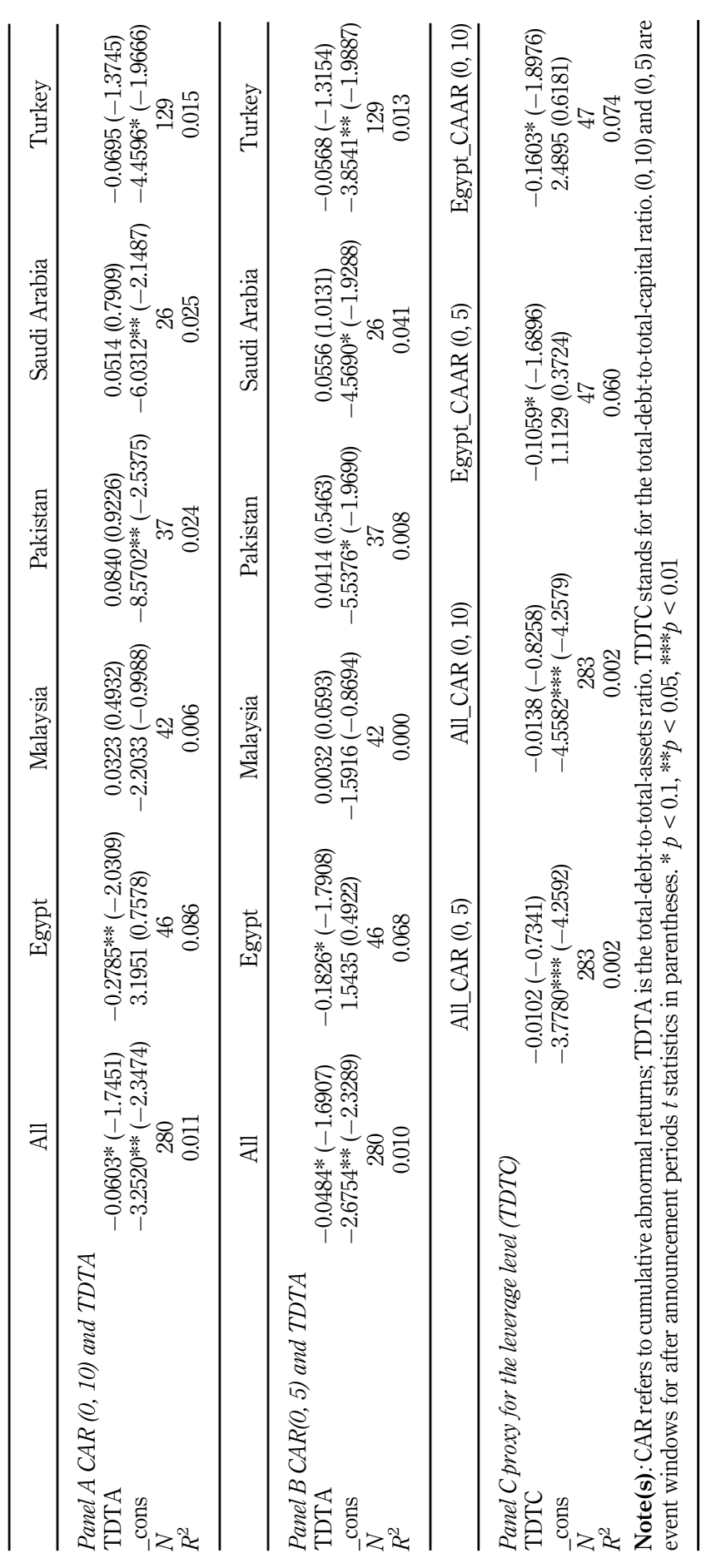

Does leverage level matter?

151

Table 5.

OLS regression results 
Panel A: $C A R(0,10)$ difference for Shariah non-compliant and compliant companies

Mean

$\begin{array}{cc}-0.0253 & -0.0633 \\ 0.0135 & 0.0207 \\ 96 & 207 \\ 301 & \\ 2.270 * * & \\ 0.024 & \end{array}$

Observations

0.0207

Df

$t$-stat

$2.270^{* * *}$

Prob.

$$
\begin{gathered}
-0.0357 \\
0.0084 \\
97 \\
303 \\
0.715
\end{gathered}
$$

Observations

\section{Table 6.}

Panel B: $C A R(0,5)$ difference for Shariah non-compliant and compliant companies

Mean

$\mathrm{df}$

Note(s): CAR refers to cumulative abnormal returns; $t$-stat represents the statistical test results for two-tailed companies

\section{independent two samples assuming equal variances. $* * p<0.05$}

Figure 4.

CAR comparison for Shariah non-compliant and compliant companies

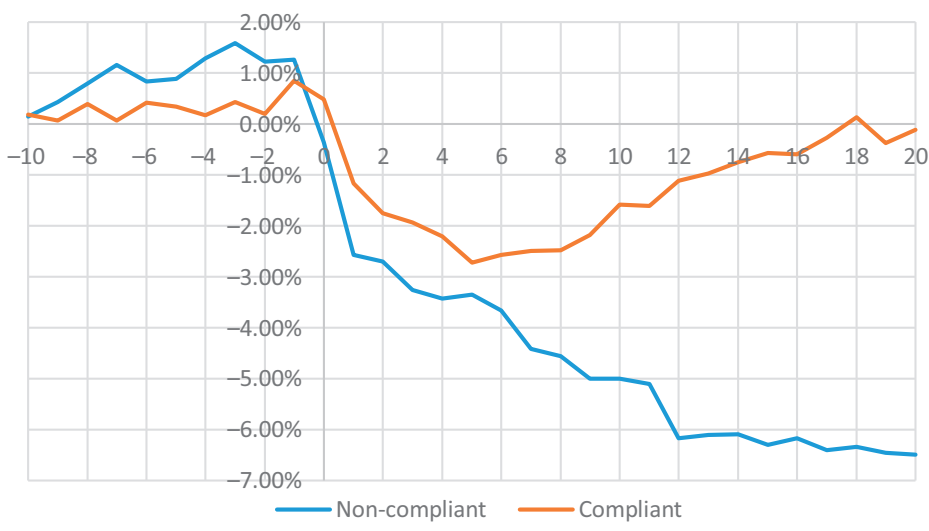

profitability after the capital raise is less possible for non-compliant firms. Jung et al. (1996) and De Jong and Veld (2001) report that when the market could judge the purpose of the equity issue, a less negative stock price reaction is observed.

\section{Conclusion}

Raising capital via rights issue is an alternative source to interest-bearing financing in Islamic countries. This paper aims to examine how the announcements of rights issues are perceived by investors in five Islamic countries and whether the leverage level of firms is a determinant on the variation in share prices around announcement days. Then, study also aims to show if return anomaly differs according to Shariah compatibility. First, we perform the event study technique to detect return anomaly on the sampled countries. Results show that strong return anomaly holds for Egypt and Turkey for post-announcement periods, 
which are consistent with the existing literature. For Pakistan, abnormal return is significant only in one case. Robust test results do not support the presence of return anomaly in Malaysia and Saudi Arabia. Second, one-way ANOVA and OLS regression analyses are conducted to understand the leverage level effect on abnormal returns. Result for Egypt is found significant with a negative sign. This refers that when highly leveraged companies announce a rights issue, abnormal returns occur more negative than low-leveraged ones in this country. Findings are robust when an alternative proxy is used for the debt level. Finally, average cumulated abnormal returns for Shariah-compliant and non-compliant firms are compared. With the passing of days, the return performance of Shariah-compliant firms is distinguished from others.

We conclude that market inefficiency exists among the stock markets of the sample countries in which negative market reaction is detected after the rights issue announcements. A possible explanation of the inefficiency is that there exists information asymmetry between investors and company managers. In general, investors evaluate the rights issue announcement as a bad signal, which means that the company may not perform well operationally or financially. Thus, they want to sell their shares after the announcement. Return anomaly magnitude can be diminished by increasing the number of alternative sources of long-term financing in these countries. Also, since short-term investors could be one reason for the negative market reaction, regulatory bodies should discourage them by applying some level of tax on their capital gains that are obtained during short-term transactions. Finally, the credibility of Shariah-compliant firms seems higher since negative abnormal returns are disappeared within 20 days after the announcement. Although the reaction is negative in general for both groups, the market is convinced about the use of proceeds that Shariah-compliant firms are more likely to direct newly raised capital in more profitable activities than non-compliant ones. Thus, existing shareholders in Shariahcompliant companies are recommended to participate in the offering to minimize the wealth loss caused after the announcement. Also, our findings suggest that investors who do not own shares of these companies can take advantage of undervalued prices on average if they invest five days after the announcement. This paper contributes to the existing literature regarding market reaction during rights issue announcements from the perspective of Islamic countries and Shariah compliance. We plan to increase the number of countries together with a wider number of variables for a future study. Also, an industry-based investigation will allow us to examine whether return anomaly differs according to the operational fields of the companies. Analyzing the long-term price performance of the right issuing companies is also on the agenda.

\section{References}

Adaoglu, C. (2006), "Market reaction to 'unsweetened' and 'sweetened' rights offerings in an emerging European stock market", Journal of Multinational Financial Management, Vol. 16 No. 3, pp. 249-268.

Al-Khazali, O., Lean, H.H. and Samet, A. (2014), "Do Islamic stock indexes outperform conventional stock indexes? A stochastic dominance approach", Pacific-Basin Finance Journal, Vol. 28, pp. 29-46.

Alam, N. and Rajjaque, M.S. (2016), "Sharỉah-compliant equities: empirical evaluation of performance in the European market during credit crunch", in Harrison, T. and Ibrahim, E. (Eds), Islamic Finance, Palgrave Macmillan, Cham, pp. 122-140.

Alhashel, B.S. and Alojayan, H.H. (2015), "Drivers of price reaction to rights issue announcements in the Kuwait stock exchange", Applied Economics, Vol. 47 No. 59, pp. 6425-6437, doi: 10.1080/ 00036846.2015 .1071476 .

Does leverage level matter? 
IES

28,2

Ariff, M., Khan, W.A. and Baker, K.H. (2007), "Are share price reactions to rights offerings sensitive to different economic conditions?”, Journal of Asia Business Studies, Vol. 1 No. 2, pp. 10-20.

Armitage, S. (1995), "Event study methods and evidence on their performance", Journal of Economic Surveys, Vol. 9 No. 1, pp. 25-52.

Ashraf, D., Felixson, K., Khawaja, M. and Hussain, S.M. (2017), "Do constraints on financial and operating leverage affect the performance of Islamic equity portfolios?", Pacific-Basin Finance Journal, Vol. 42, pp. 171-182.

Balachandran, B., Faff, R., Theobald, M. and Van Zijl, T. (2012), "Rights offerings, subscription period, shareholder takeup, and liquidity", Journal of Financial and Quantitative Analysis, Vol. 47 No. 1, pp. 213-239.

Bhatt, V. and Sultan, J. (2012), "Leverage risk, financial crisis, and stock returns: a comparison among Islamic, conventional, and socially responsible stocks", Islamic Economic Studies, Vol. 20 No. 1, pp. 87-143.

Cowan, A.R. (1992), "Nonparametric event study tests", Review of Quantitative Finance and Accounting, Vol. 2 No. 4, pp. 343-358.

De Jong, A. and Veld, C. (2001), "An empirical analysis of incremental capital structure decisions under managerial entrenchment", Journal of Banking and Finance, Vol. 25 No. 10, pp. 1857-1895.

Eckbo, B.E. and Masulis, R.W. (1992), "Adverse selection and the rights offer paradox", Journal of Financial Economics, Vol. 32 No. 3, pp. 293-332.

Farooq, O. and AbdelBari, A. (2015), "Earnings management behaviour of Sharı'ah-compliant firms and non-Sharỉah-compliant firms", Journal of Islamic Accounting and Business Research, Vol. 6 No. 2, pp. 173-188.

Hansen, R.S. (1988), "The demise of the rights issue”, Review of Financial Studies, Vol. 1 No. 3, pp. 289-309.

Heron, R.A. and Lie, E. (2004), "A comparison of the motivations for and the information content of different types of equity offerings", Journal of Business, Vol. 77 No. 3, pp. 605-632.

Holderness, C.G. and Pontiff, J. (2016), "Shareholder nonparticipation in valuable rights offerings: new findings for an old puzzle", Journal of Financial Economics, Vol. 120 No. 2, pp. 252-268.

Iqbal, A. (2008), "The importance of the sequence in UK rights issues", Journal of Business Finance and Accounting, Vol. 35 Nos 1-2, pp. 150-176.

Ismail, W.A.W., Kamarudin, K.A. and Sarman, S.R. (2015), "The quality of earnings in Shariahcompliant companies: evidence from Malaysia”, Journal of Islamic Accounting and Business Research, Vol. 6 No. 1, pp. 19-40.

Jawadi, F., Jawadi, N. and Louhichi, W. (2014), "Conventional and Islamic stock price performance: an empirical investigation”, International Economics, Vol. 137, pp. 73-87.

Jung, K., Kim, Y.C. and Stulz, R. (1996), “Timing, investment opportunities, managerial discretion, and the security issue decision”, Journal of Financial Economics, Vol. 42 No. 2, pp. 159-185.

Kabir, R. and Roosenboom, P. (2003), "Can the stock market anticipate future operating performance? Evidence from equity rights issues”, Journal of Corporate Finance, Vol. 9 No. 1, pp. 93-113.

Kang, J.K. and Stulz, R.M. (1996), "How different is Japanese corporate finance? An investigation of the information content of new security issues", Review of Financial Studies, Vol. 9 No. 1, pp. 109-139.

Kim, J.H. and Song, K. (2020), "The choice of SEO method in Korea: rights vs. public offers", Journal of Financial Markets, Vol. 51, doi: 10.1016/j.finmar.2020.100532.

Kim, W., Ko, Y. and Wang, S.F. (2019), "Debt restructuring through equity issues”, Journal of Banking and Finance, Vol. 106, pp. 341-356.

Kothari, S.P. and Warner, J.B. (2007), "Econometrics of event studies", in Eckbo, B.E. (Ed.), Handbook of Empirical Corporate Finance, Elsevier, pp. 3-36, doi: 10.1016/B978-0-444-53265-7.50015-9. 
Lee, C.C., Poon, W.C. and Sinnakkannu, J. (2014), "Why are rights offers in Hong Kong so different?", Pacific-Basin Finance Journal, Vol. 26, pp. 176-197.

Mateus, C., Farinha, J. and Soares, N. (2017), "Price discounts in rights issues: why do managers insist on what investors hate?", European Business Review, Vol. 29 No. 4, pp. 457-475.

Rejeb, A.B. and Arfaoui, M. (2019), "Do Islamic stock indexes outperform conventional stock indexes? A state space modeling approach", European Journal of Management and Business Economics, Vol. 28 No. 3, pp. 301-322.

Saiti, B., Bacha, O.I. and Masih, M. (2014), "The diversification benefits from Islamic investment during the financial turmoil: the case for the US-based equity investors", Borsa Istanbul Review, Vol. 14 No. 4, pp. 196-211.

Sartika, F. and Djumair, S. (2016), "The effect of growth opportunities, issue size, leverage, ownership concentration, and subscription price discount toward cumulative abnormal return: study on right issue event”, Global Journal of Business and Social Science Review, Vol. 4 No. 3, pp. 98-107.

Slovin, M.B., Sushka, M.E. and Lai, K.W. (2000), "Alternative flotation methods, adverse selection, and ownership structure: evidence from seasoned equity issuance in the UK", Journal of Financial Economics, Vol. 57 No. 2, pp. 157-190.

Tan, R.S., Chng, P.L. and Tong, Y.H. (2002), "Private placements and rights issues in Singapore", Pacific-Basin Finance Journal, Vol. 10 No. 1, pp. 29-54.

Tas, O., Tokmakcioglu, K., Ugurlu, U. and Isiker, M. (2016), “Comparison of ethical and conventional portfolios with second-order stochastic dominance efficiency test", International Journal of Islamic and Middle Eastern Finance and Management, Vol. 9 No. 4, pp. 492-511.

Tsangarakis, N.V. (1996), "Shareholder wealth effects of equity issues in emerging markets: evidence from rights offerings in Greece", Financial Management, Vol. 25 No. 3, pp. 21-32.

\section{Further reading}

Al Meezan Investment (2020), "Companies for KMI-30 index recomposition based on accounts for June 2019", available at: https://www.almeezangroup.com/investor-education/Shariah-methodology/ (accessed 30 June 2020).

Argaam Investment (2020), "Shariah compliant companies for Tadawul all-share index (TASI)", available at: https://www.argaam.com/en/company/Shariahcompanies/1/4/3 (accessed 30 June 2020).

BMD (2020), "Katılım endeksi uygunluk durumu ve arındırma oranları (Participation index screening results as of 1 July 2020)", available at: https://bmd.com.tr/page/duyuru_detay/33/katilimendeksi-uygunluk-durumu-ve-arindirma-oranlari-hk.htm (accessed 30 June 2020).

MacKinlay, A.C. (1997), "Event studies in economics and finance", Journal of Economic Literature, Vol. 35 No. 1, pp. 13-39.

Security Comission Malaysia (2020), "List of Sharỉah-compliant securities as at 29 may 2020", available at: https://www.sc.com.my/development/islamic-capital-market/list-of-Sharıahcompliant-securities-by-scs-Shariah-advisory-council (accessed 30 June 2020).

Ziraat Portfoy (2020), "List of Sharỉah-compliant companies as at 1 July 2020", available at: https:// www.ziraatportfoy.com.tr/TRK/endeks-sirketleri (accessed 30 June 2020).

\section{Corresponding author}

Murat Isiker can be contacted at: isikermurat@hotmail.com

For instructions on how to order reprints of this article, please visit our website:

www.emeraldgrouppublishing.com/licensing/reprints.htm

Or contact us for further details: permissions@emeraldinsight.com
Does leverage level matter? 